\title{
Dental Cervical Lesions: How the Etiologies Imply in Different Approaches for Long-Lasting Performance
}

Lesões Cervicais Dentárias: Como as Etiologias Implicam em Diferentes Abordagens para um Desempenho Duradouro Lesiones Cervicales Dentales: Cómo las Etiologías Implican en Diferentes Enfoques para un Rendimiento Duradero

Giovanna Speranza ZABEU

Department of Operative Dentistry, Endodontics and Dental Materials, Bauru School of Dentistry, University of São Paulo (FOB-USP), 17012-901, Bauru - SP, Brazil

School of Dentistry, Centro Universitário Sagrado Coração (UNISAGRADO), 17011-160, Bauru - SP, Brazil

https://orcid.org/0000-0001-5044-6690

Victor MOSQUIM

Department of Operative Dentistry, Endodontics and Dental Materials, Bauru School of Dentistry, University of São Paulo (FOB-USP), 17012-901, Bauru - SP, Brazil

https://orcid.org/0000-0003-0442-5690

Natália Almeida BASTOS-BITENCOURT

Department of Operative Dentistry, Endodontics and Dental Materials, Bauru School of Dentistry, University of São Paulo (FOB-USP), 17012-901, Bauru - SP, Brazil

https://orcid.org/0000-0002-8365-0978

Daniella Cristo SANTIN

Department of Operative Dentistry, Endodontics and Dental Materials, Bauru School of Dentistry, University of São Paulo (FOB-USP), 17012-901, Bauru - SP, Brazil

https://orcid.org/0000-0003-4353-6203

Maria Angélica Silvério AGULHARI

Department of Operative Dentistry, Endodontics and Dental Materials, Bauru School of Dentistry, University of São Paulo (FOB-USP), 17012-901, Bauru - SP, Brazil

https://orcid.org/0000-0003-3945-4205

Linda WANG

Department of Operative Dentistry, Endodontics and Dental Materials, Bauru School of Dentistry, University of São Paulo (FOB-USP)

17012-901, Bauru - SP, Brazil

https://orcid.org/0000-0001-6308-2769

\begin{abstract}
Particularities of dental cervical lesions require distinct approaches from preventive to therapeutic managements. Therefore, practitioners depend on their etiology, selected materials and patient involvement to provide conditions to effective performance. Through representative clinical scenarios, the main considerations regarding carious and non-carious cervical lesions (NCCL) are reported for the determination of strategies. Details regarding the disease, lesions aspects, evolution and involvement or not of the periodontal tissues are considered in their decision. In conclusion, their long-lasting resolution is determined by a complex combination of biomechanical factors and therapeutic strategies for each particular lesion, regardless of the cervical location solely.
\end{abstract}

Descriptors: Dental Caries; Composite Resins; Dentin; Glass lonomer Cements; Tooth Wear.

Resumo

As particularidades das lesões cervicais dentárias direcionam a abordagens distintas, desde a preventiva até a terapêutica. Portanto, os profissionais dependem de sua etiologia, materiais selecionados e envolvimento do paciente para oferecer condições para um desempenho eficaz. Por meio de cenários clínicos representativos, as principais considerações a respeito das lesões cariosas e cervicais não cariosas (LCNC) são relatadas para a determinação das estratégias. Detalhes sobre a doença, aspectos das lesões, evolução e envolvimento ou não dos tecidos periodontais são levados em consideração na decisão. Em conclusão, sua resolução duradoura é determinada por uma combinação complexa de fatores biomecânicos e estratégias terapêuticas para cada lesão em particular, não dependendo apenas da localização na região cervical.

Descritores: Cárie Dentária; Resinas Dentárias; Dentina; Cimentos de lonômeros de Vidro; Desgaste dos Dentes.

Resumen

Las particularidades de las lesiones cervicales dentales direcionan distintos enfoques, desde los tratamientos preventivos hasta los terapéuticos. Por lo tanto, los médicos dependen de su etiología, materiales seleccionados y participación del paciente para proporcionar las condiciones para un desempeño efectivo. A través de escenarios clínicos representativos, se reportan las principales consideraciones sobre lesiones cariosas y cervicales no cariosas (LCNC) para la determinación de estrategias. En su decisión se consideran detalles sobre la enfermedad, aspectos de las lesiones, evolución y afectación o no de los tejidos periodontales. En conclusión, su resolución duradera está determinada por una combinación compleja de factores biomecánicos y estrategias terapéuticas para cada lesión en particular, no solo dependiendo de la ubicación en la región cervical.

Descriptores: Caries Dental; Resinas Compuestas; Dentina; Cementos de lonómero Vitreo; Desgaste de los Dientes.

INTRODUCTION

Despite the significant reduction in prevalence, dental caries still represents the most common disease that irreversibly compromise dental tissues ${ }^{1,2}$. Historically, carious lesions in different tooth surfaces lead to the creation of a series of classifications and protocols to ease the communication between clinicians and to stablish a correct management of such lesions ${ }^{2-4}$. One example is the classification of artificial cavities, preconized by G.V. Black ${ }^{5}$.
According to this classification, Class V cavities was the term attributed to carious lesions affecting the cervical area of buccal and/or lingual surfaces, resulting in cavities limited by mesial, distal, occlusal, cervical and axial walls.

More recently, other lesions with etiologies different from those of dental caries are being discussed to affect teeth in the cervical area, and these lesions are called noncarious cervical lesions (NCCLs) ${ }^{6-9}$. This term is 
usually associated with a progressive surface loss of dental tissue in the cervical area caused by erosion (biocorrosion), abrasion and/or abfraction, which result in lesions distinct from carious ones $^{6-8}$. Some reports have addressed the tensions generated in this area upon function of the teeth ${ }^{6,10}$. Given the lack of proximal walls, the amount of stress a restorative material have to bear lead to different procedures than when carious lesions are being restored. Also, the different etiology between carious and NCCLs lead to differences in the substrate, in which dental caries generates a demineralized dentin because of bacterial activity $^{1}$, whilst NCCLs frequently stimulate the hypermineralization of the dentin ${ }^{11-14}$.

Given these differences regarding the cavity design and in the morphology of the substrate, the restorative treatments require different procedures to achieve reliable bonding and adequate performance overtime. Therefore, the aim of this work is to present four clinical cases with lesions derived from different etiologies to help professionals to diagnose these lesions and to guide them to properly understand the benefits of different restorative approaches.

CLINICAL CASES

\section{- Case 1 - Cervical carious lesion}

Carious lesions in the cervical area can be recognized by some clinical signs, such as the presence of biofilm, gingival inflammation and easy bleeding. Other cervical surfaces from adjacent teeth may also be cavitated, restored or present typical white spot lesions, which indicate early onsets of demineralization ${ }^{1,15}$.

In patients with carious lesions, the medical history may supply data about a cariogenic diet, inadequate oral hygiene or even lack of information about these habits. It is essential to provide the instructions regarding diet and hygiene habits even if restorative treatment is necessary ${ }^{16}$.

Before the restorative treatment, contaminated dentin should be selectively removed and demineralized dentin, in which the collagen matrix is preserved, should be maintained ${ }^{4}$. This technique helps to preserve tissue with potential to be remineralized, which may improve the structure's ability to resist upon mechanical forces ${ }^{17,18}$. Based on this reasons, restoration with bioactive materials are a relevant clinical approach, since these materials require less tissue removal and may induce tooth remineralization ${ }^{4}$.

In this clinical report, a 26-year-old male patient presented cervical carious lesions and an esthetic complaint due to anterior teeth misalignment. Under clinical examination, previous restorations and new white spots lesions were noted, as well as the presence of biofilm, gingival inflammation and other class $\mathrm{V}$ lesions (Figure 1). Patient reported rare use of dental floss and difficulties in performing oral hygiene, mainly because of teeth misalignment.

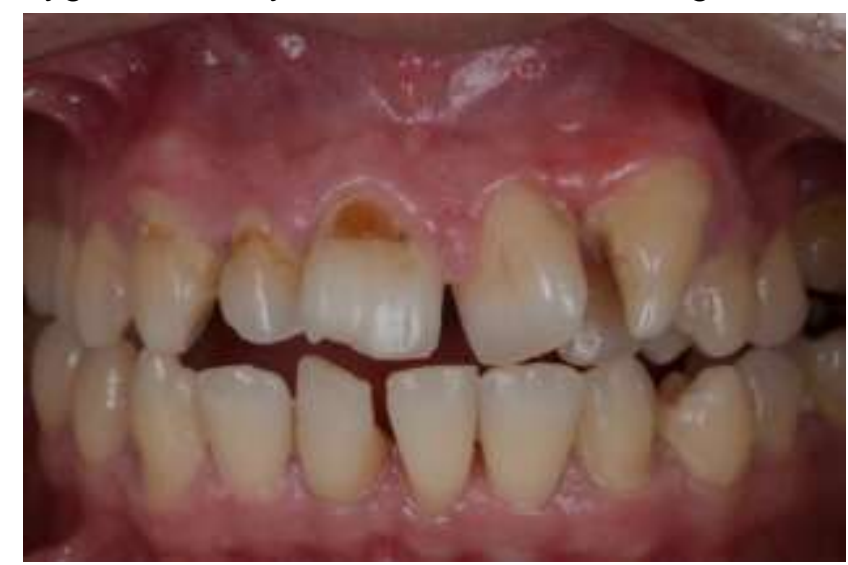

Figure 1: Intraoral view highlights the deficiency in oral hygiene and class $\mathrm{V}$ lesion in the right maxillary central incisor.

First, the patient was oriented regarding oral hygiene and dietary habits. Then, to minimize the plaque accumulation and reestablish function and esthetic, Class V restorations were performed. However, the patient was advised that an orthodontic treatment could also help to establish his oral health and improve his esthetics.

After shade selection and rubber dam isolation, carious tissue was removed until leather consistency was reached ${ }^{4}$. Finally, a bevel at the occlusal cavosurface margin was done with a flame-shaped diamond bur (Figures 2 and 3). For the adhesive procedures, conventional etch-and-rinse hybridization was performed. Dentin was etched with 37\% phosphoric acid for 15 seconds and enamel was etched for 30 seconds. Once the cavity was rinsed and dried with absorbent paper, a hydrophilic primer was used, followed by a hydrophobic bonding agent (Adper ${ }^{\mathrm{TM}}$ Scotchbond Multipurpose, 3M ESPE, St Paul, MN, USA). The adhesive was light-cured for 10 seconds with a LED device (DBD 686 D700 Dabi Atlante, Ribeirão Preto, SP, Brazil). The teeth were restored with resin composite (Vittra APS, FGM, Joinvile, SC, Brazil) followed by finishing and polishing processes, which were conducted with a carbide bur, followed by the full sequence of Sof-Lex aluminum oxide polishing discs (Sof-Lex, 3M ESPE, São Paulo, SP, Brazil) and a felt disc associated with a diamond polishing paste (Diamond Excel, FGM, Joinvile, SC, Brazil) (Figure 4). In this case, the success of the treatment relies on educating patients 
regarding their hygiene and dietary habits to reverse the etiological factors. The restorative treatment should restore the esthetics of the area and should allow the surface to be easily cleaned by the patient.

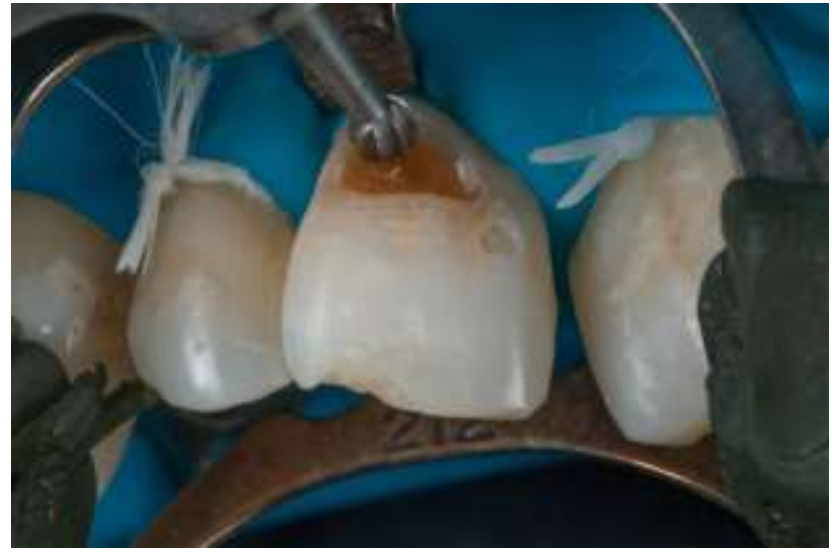

Figure 2: Removal of the carious tissue with a carbide bur compatible with cavity's size, preserving maximum of tissue.

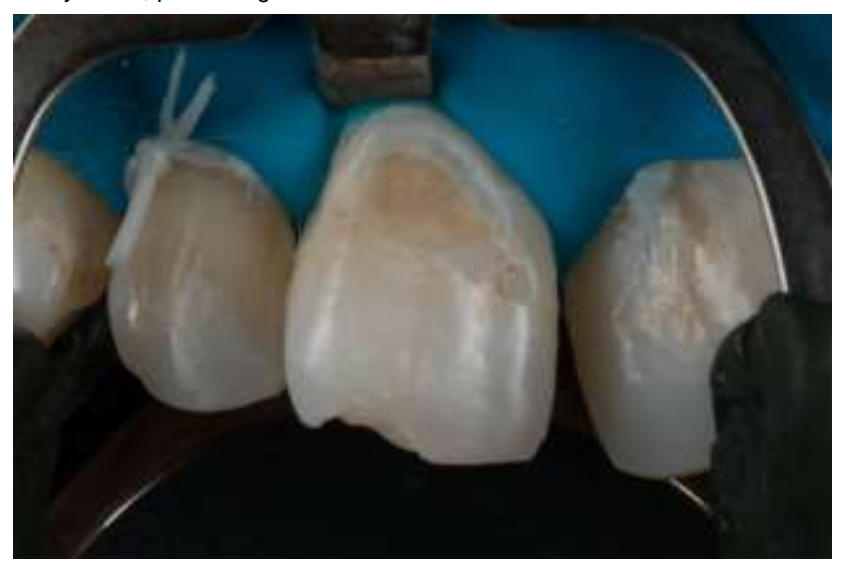

Figure 3: Appearance of the cavity after carious tissue removal.

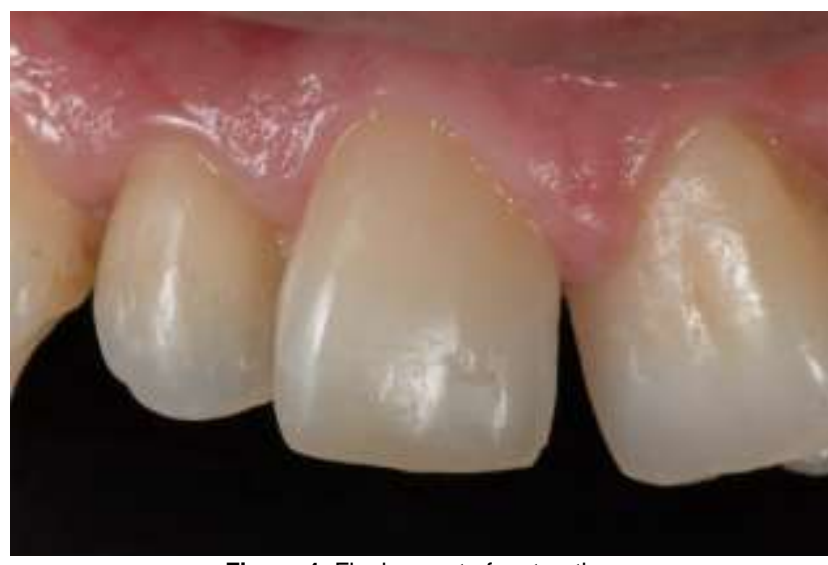

Figure 4: Final aspect of restoration.

\section{- Case 2 - Cervical carious lesion with} periodontal compromise

When carious disease is not arrested, cervical lesions can progress and affect the adjacent periodontal structures, as described in this case. This 60-year-old male patient complained about intense dentin sensitivity. Class $\mathrm{V}$ carious lesion in left mandibular canine was observed, extending sub gingivally with biological distance compromise (Figure 5). The treatment plan included a trans-surgical direct restoration. All surgical procedures were performed under strict biosecurity standards. After local anesthesia, the full-thickness flap was created to expose the bone. Because the distance from the lesion terminus to the bone crest was greater than $1 \mathrm{~mm}$, there was no need for osteotomy. When the surgical procedures were finished, restorative procedures were initiated under rubber dam isolation. Carious tissue was selectively removed until leatherconsistent dentin was reached. Because it was a deep cavity, calcium hydroxide cement (Hydro C, Dentsply/Sirona, York, Pennsylvania, USA) was placed to protect the dentin-pulp complex. Glass-ionomer cement (Glaslonomer FX ULTRA, Shofu, Kyoto, Japan) was chosen as the restorative material. The finishing and polishing steps were conducted with a flameshaped carbide bur (KG Sorensen Ind. e Com. Ltda., Barueri, SP, Brazil) and Jiffy Polisher Cups (Ultradent Products, Inc., South Jordan, UT, USA), followed by a felt disc associated with a diamond polishing paste (Diamond Excel, FGM, Joinvile, SC, Brazil) (Figures 6-8). After the restoration was concluded, rubber dam was removed, and the flaps was sutured (Figure 9). After 15 days, the suture was removed, and the periodontal tissue and the restoration presented a healthy aspect (Figure 10). After 1 year, the restoration was clinically adequate, and the patient reported no sensitivity upon air blast (Figure 11).

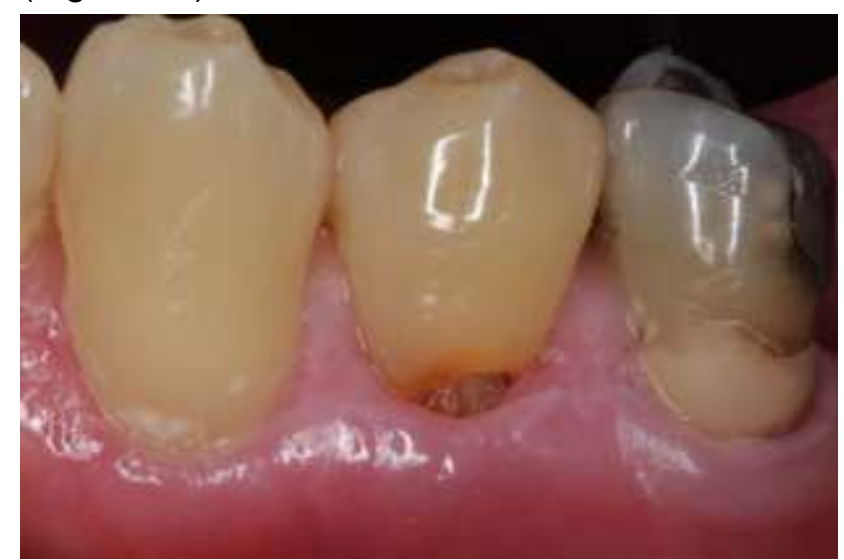

Figure 5: Initial aspect of the left mandibular canine affected by caries with periodontal involvement.

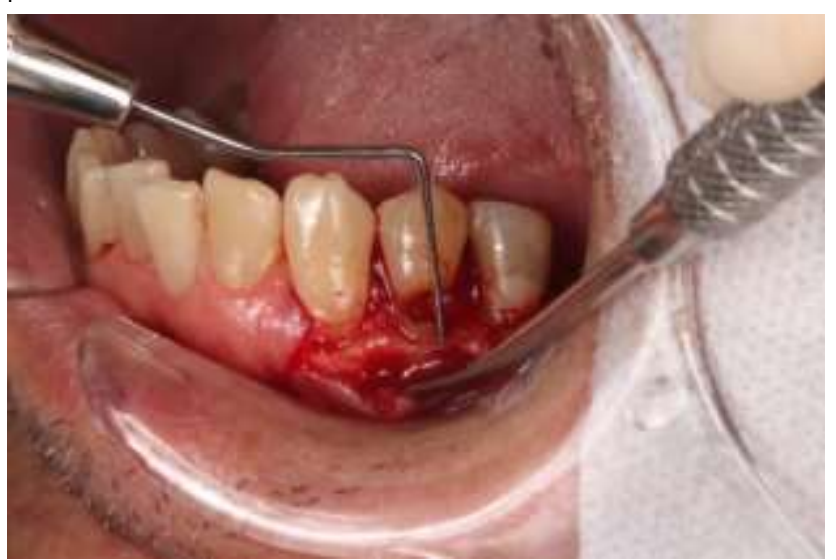

Figure 6: Total flap to expose bone tissue and the cavosurface margin. 


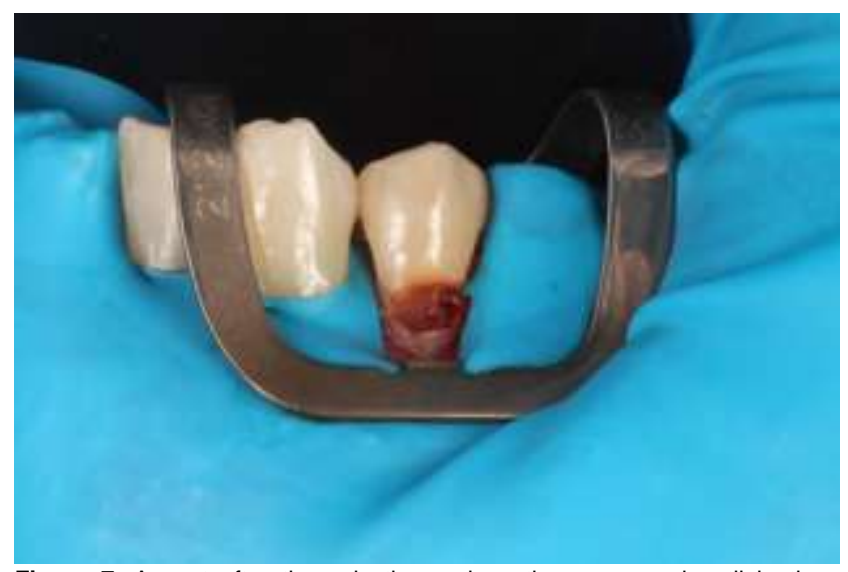

Figure 7: Aspect after the selective carious tissue removal until leatherconsistent dentin.

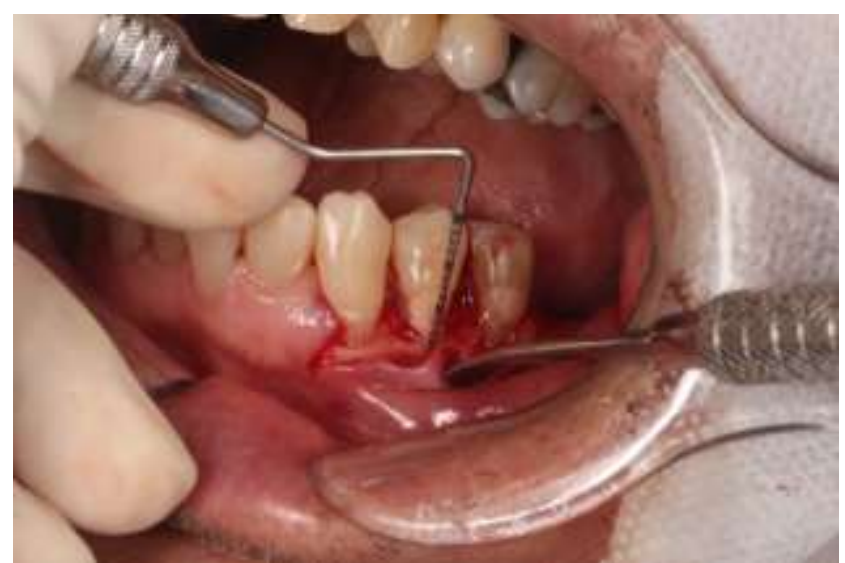

Figure 8: The aspect after restoration and checking the measurement between the lesion terminus to the crestal bone.

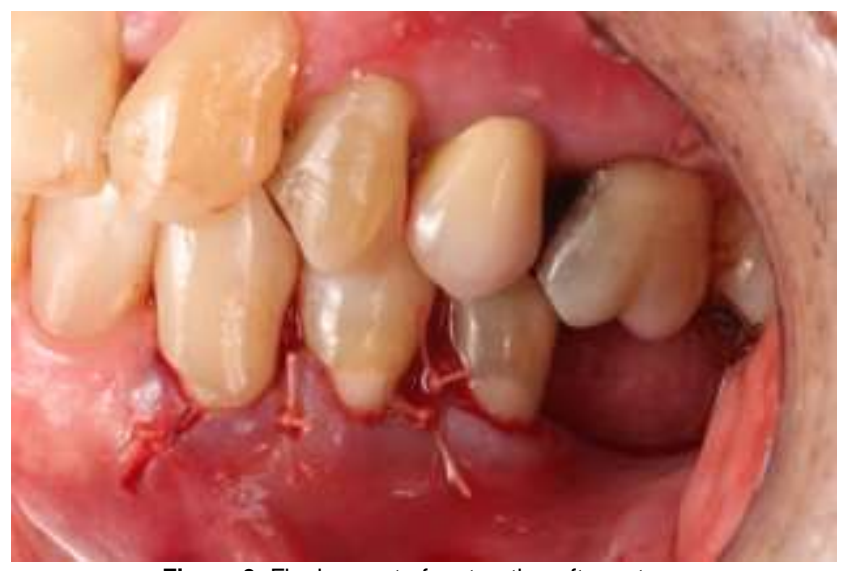

Figure 9: Final aspect of restoration after suture.

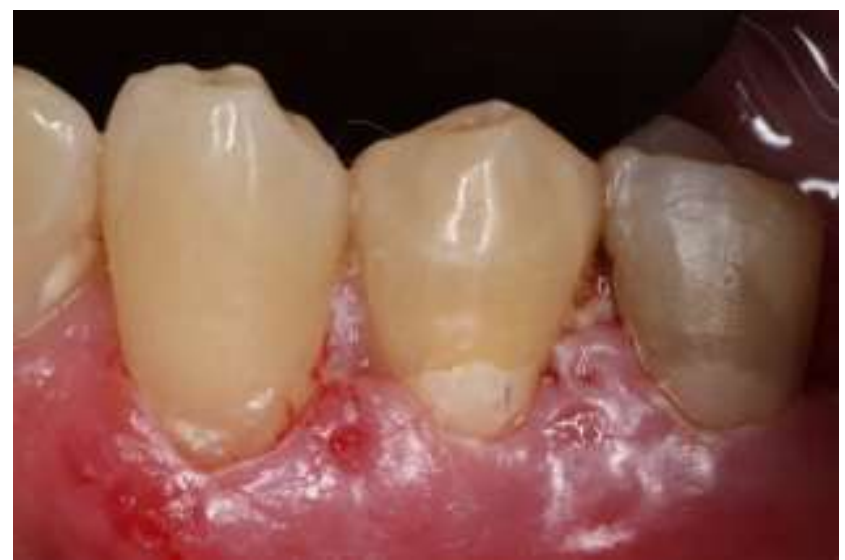

Figure 10: Suture removed and final aspect of restoration after 15 days.

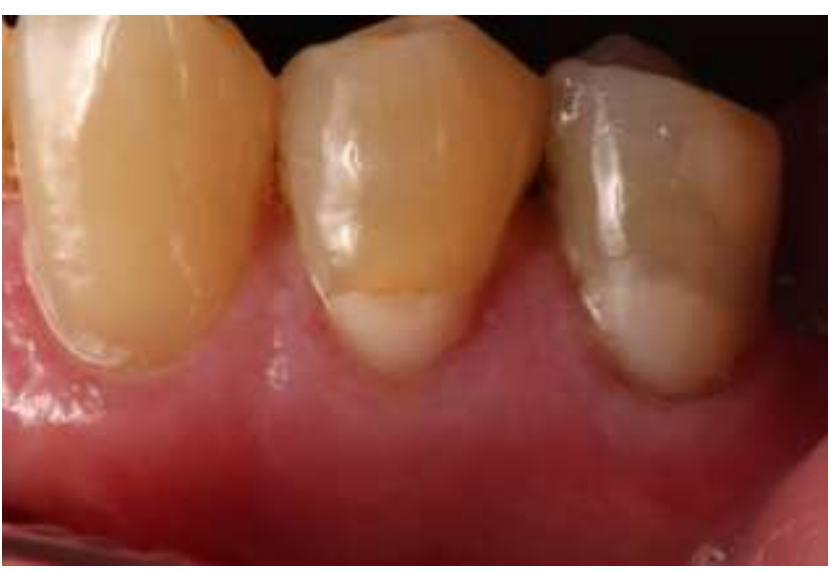

Figure 11: Follow-up after 1 year.

\section{- Case 3 - Erosive tooth wear}

A 35-year-old male patient was referred to local clinic complaining about hypersensitivity on his canines and first premolars.

Under clinical examination, general wear was diagnosed at all buccal surfaces of anterior teeth, also affecting cervical dentin in all maxillary and mandibular canines and first premolars. The lesions were disk-shaped, shallow, without defined margins, and with enamel in all margins (Figures 12).

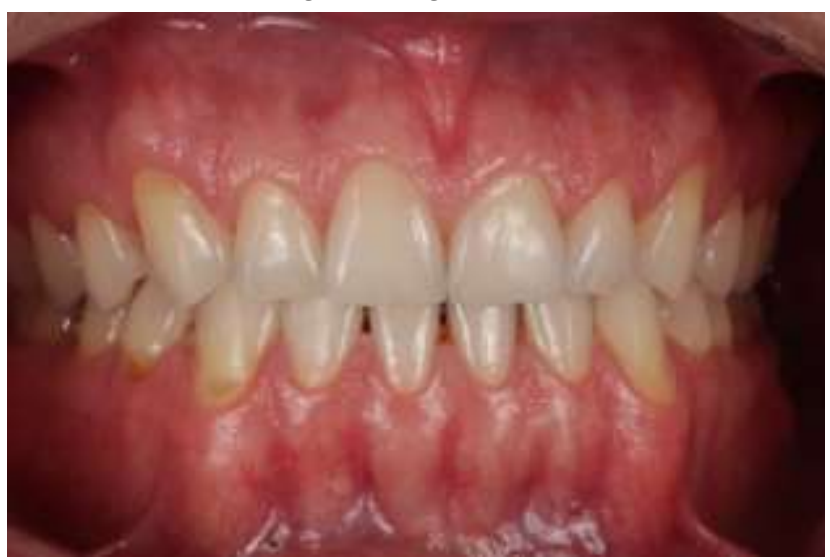

Figure 12: General overview of dental situation showing erosive lesions on almost all buccal surfaces of anterior teeth.

During the anamnesis, the patient reported a daily intake of lemon juice on an empty stomach in the morning. This lead the clinician to diagnose erosive tooth wear. The treatment plan included instructing the patient regarding the causal factors of erosive tooth wear and dietary instructions, followed by restorative treatment in the regions where dentin was exposed. Because it is an esthetic area, resin composite was chosen as the restorative material. After shade selection and rubber dam isolation, the enamel was beveled at the incisal cavosurface margin and selectively etched with $37 \%$ phosphoric acid for 10 seconds. Then, a 2step self-etching bonding system (Clearfil SE Bond, Kuraray, Okayama, Japan) was applied, followed by the placement of a nanohybrid dental composite (Spectra Smart, Dentsply/Sirona, York, Pennsylvania, USA). The 
finishing and polishing steps were conducted similarly to case 1 (Figures 13-17).

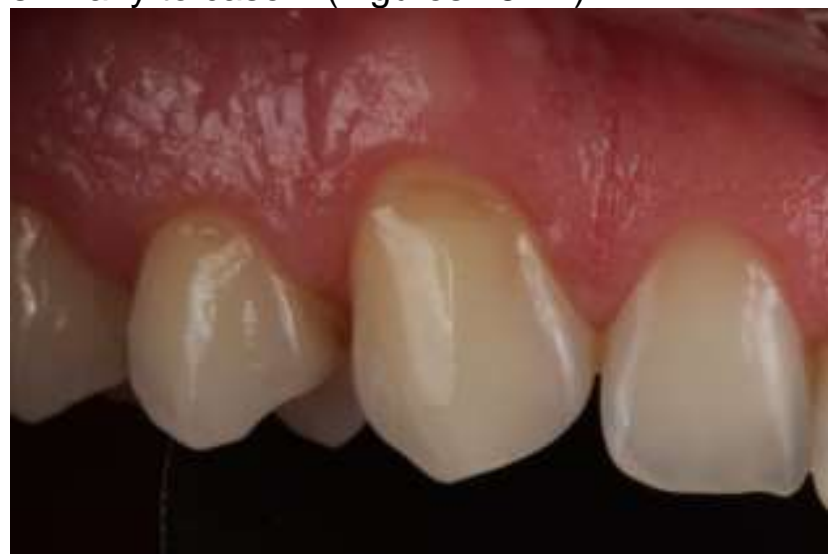

Figure 13: Shallow lesions, without defined margins, and disk-shaped on the right maxillary canine and premolar. Restorative procedures exemplified in the right maxillary premolar.

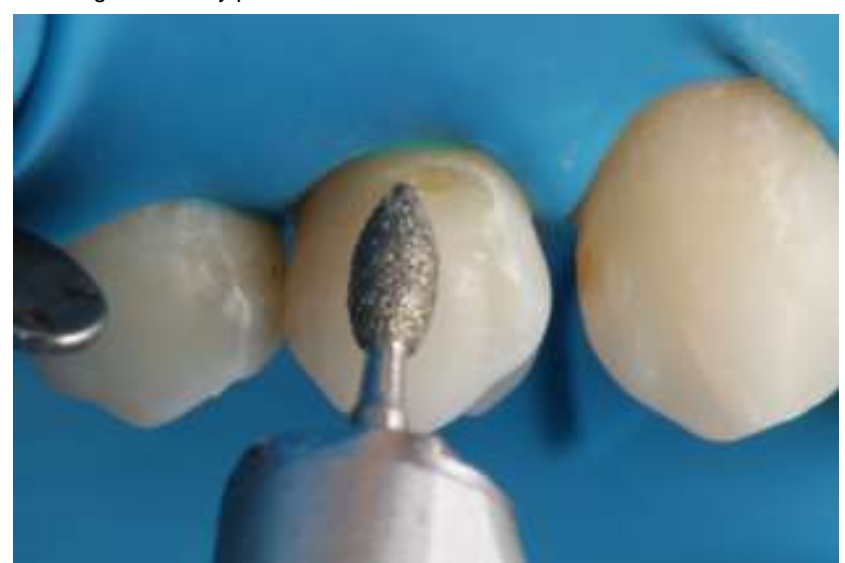

Figure 14: Bevel performed at the cavosurface margin with FG1111 at low speed.

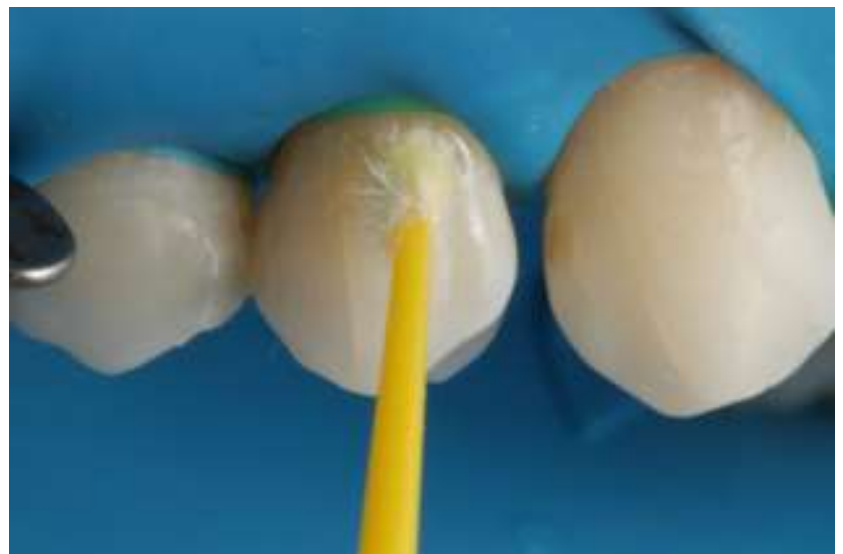

Figure 15: Bonding procedures, with $37 \%$ phosphoric acid application for 10 seconds on enamel, followed by application of a 2-step self-etching bonding system (Clearfil SE Bond).

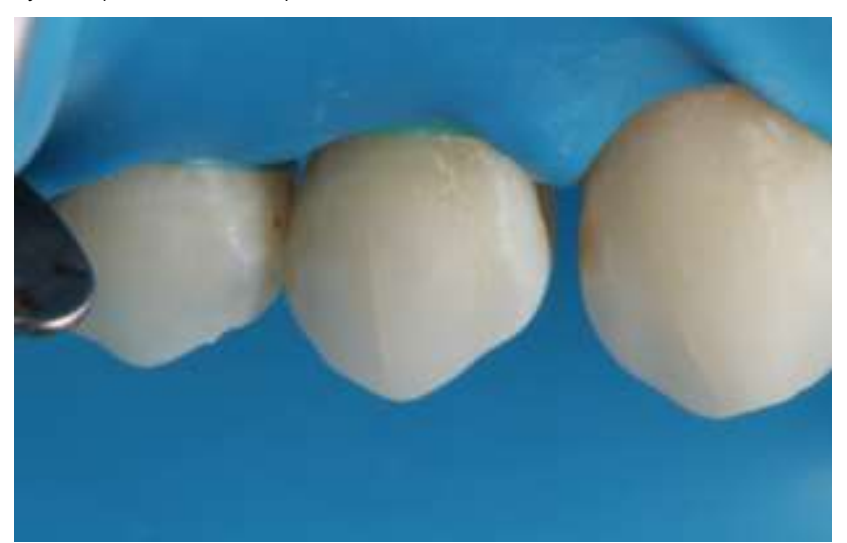

Figure 16: Final aspect of restoration.

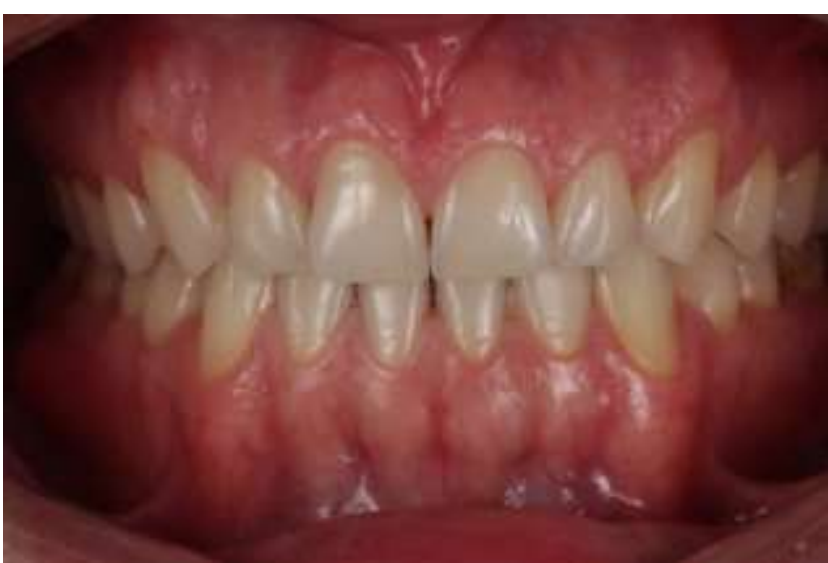

Figure 17: General overview of clinical dental situation after all restorative procedures.

After 1 year, the restorations were clinically adequate, and the patient reported no sensitivity upon air blast. Also, the patient reported change in his eating habits, without the intake of lemon juice in the morning, as well as the reduction of acidic foods (Figure 18).

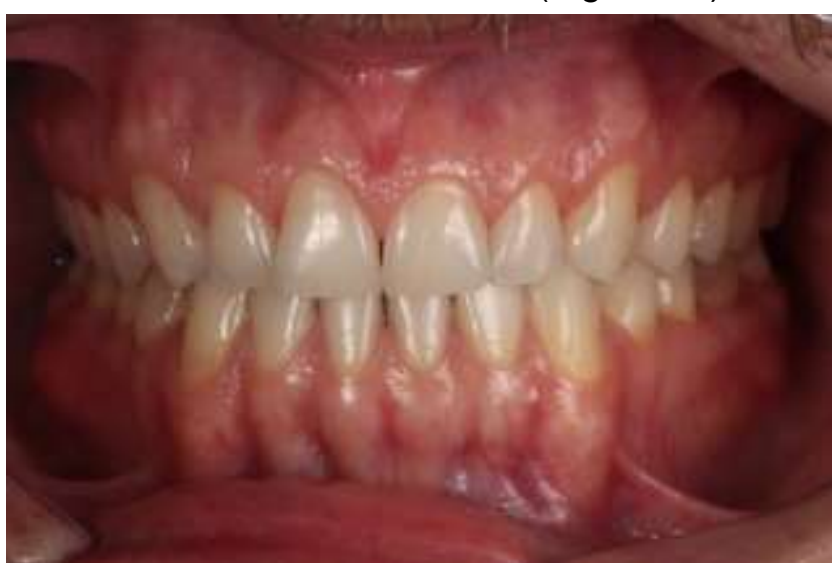

Figure 18: Follow-up after 1 year.

\section{- Case 4 - Abfraction}

A 19-year-old male patient was referred to the local clinical service. Clinical examination revealed abfraction lesions in the right mandibular first and second premolar, affecting cervical dentin, caused by occlusal overstress related to his malocclusion and loss of posterior teeth (Figure 8).

Shade selection was conducted, and low viscosity resin was chosen (Beautifil Flow Plus $X$ F03, shade A3, Shofu, Kyoto, Japan). After isolation with cotton rolls, retraction cords were inserted, and bevel was performed at the cavosurface margin. For bonding procedures, $37 \%$ phosphoric acid was applied for 10 seconds on enamel, followed by a 2-step selfetching bonding agent (FL Bond II, Shofu, Kyoto, Japan). Then, the low viscosity resin was applied, the sculpture was adjusted, and light cured for 40 seconds. The finishing and polishing steps were also conducted similarly to case 1. After polishing, the restorations were clinically adequate, and the patient reported no 
sensitivity upon air blast and cold beverages (Figures 19-22).

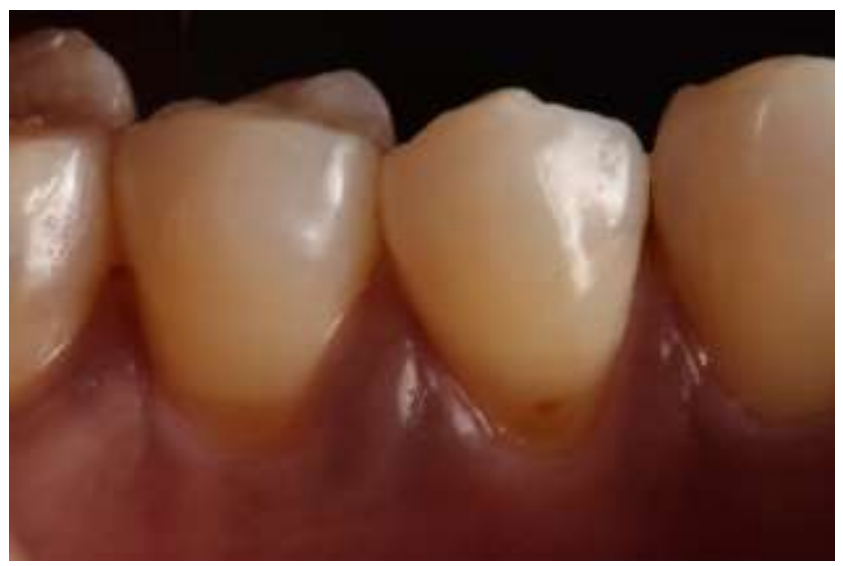

Figure 19: Initial aspect of the lesions, with exposure of dentin and enamel loss above cement-enamel junction.

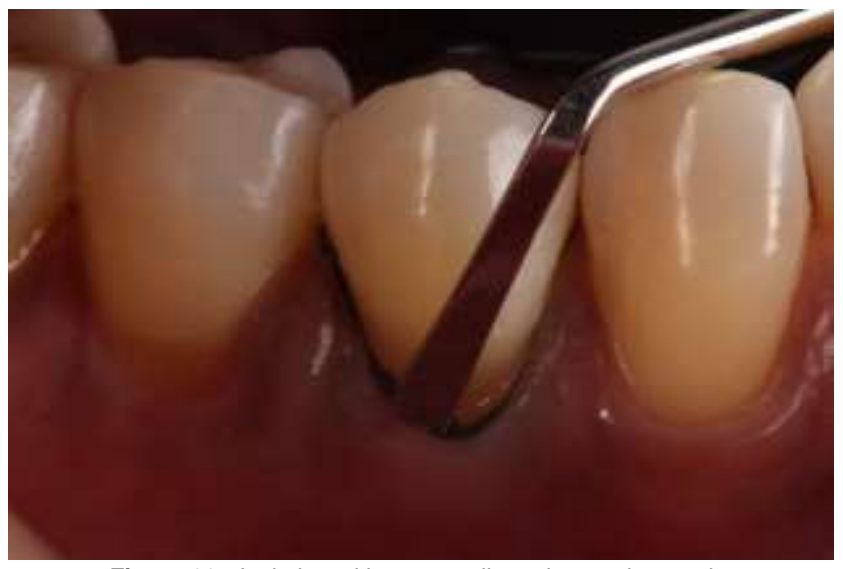

Figure 20: Isolation with cotton rolls and retraction cords.

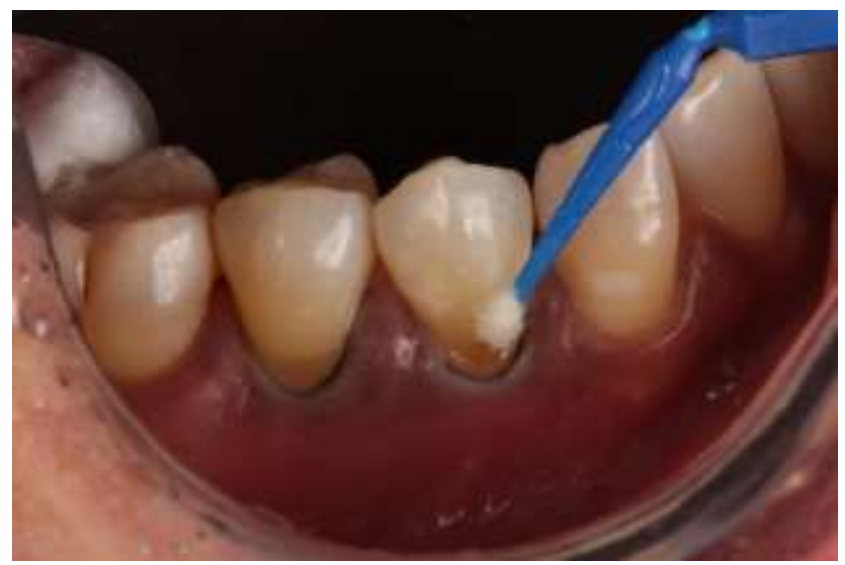

Figure 21: Bonding procedures with 2-step self-etching bonding system (Clearfil SE Bond) with selective etching on enamel.

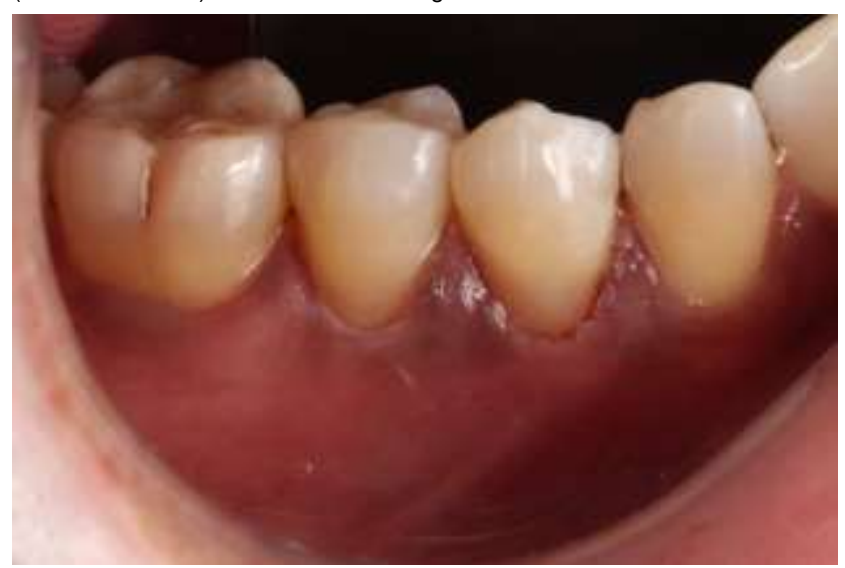

Figure 22: Final aspect of the restoration.

\section{DISCUSSION}

The term "Class $\mathrm{V}$ cavities" was firstly introduced to address carious lesions on the buccal or lingual surface of teeth, which required preparation to receive the restoration. This term, along with Class I to Class IV, composed the artificial classification proposed by G. V. Black ${ }^{5}$. However, due to other clinical lesions, such as tooth fracture and NCCLs, these terms have been used to indicate the affected area, disregarding the fact that the etiology of these latter lesions are different from carious ones.

When caries is the etiology, dentin removal will result in the formation of a cavity in which the presence of surrounding walls favors the retention of the restorative material ${ }^{19,20}$. However, in non-carious etiologies (e.g. abrasion, erosion and abfraction), these lesions do not form a cavity and no preparation is conducted to create a cavity in which the material is going to be placed.

Because the NCCLs do not require soft tissue removal, a less invasive approach is required, but the retention of the restorative material can be harmed overtime. The main reasons rely on two points. The first is the hypermineralized substrate. Due to the mechanism behind the establishment of NCCLs, the tissues have time to respond to the aggressive stimuli, resulting in the deposition of minerals at the dentin tubules' apertures (i.e. sclerotic dentin). Despite being a relevant barrier against external aggressions to the pulp, the sclerotic dentin imposes a challenge to the bonding ability of resinous materials ${ }^{8,13,14}$. However, due to improvements in the formulation of the self-etching systems, this issue was overcome ${ }^{21}$, therefore these bonding systems, especially those containing functional monomers (e.g. 10-MDP or MF8P) ${ }^{22}$, should be used on hypermineralized tissues.

The second point is the material's elastic modulus. The cervical area concentrates the indirect resultant forces from physiological occlusal contacts $^{6,7}$. Depending on the intensity and direction of these forces, loss of dental tissue can happen, leading to the formation of abfraction lesions ${ }^{8,23,24}$. Therefore, the selection of the restorative material should consider its ability to replace the mechanical behavior of dentin. In these cases, the glass-ionomers and flowable resin composites are commonly employed $^{25,26}$.

For years, the glass-ionomers were the main option due to their ability to conciliate both good bonding to hypermineralized tissues and proper elastic modulus ${ }^{19,27}$. However, resinbased materials, if associated with self-etching 
systems, is an interesting alternative if esthetics is also a key condition to be reestablished ${ }^{26,27}$. It is also important to state that, despite bonding being important to achieve long-lasting results, operators should also be aware of other relevant clinical procedures, such as eventual repolishing of the restoration?

Numerous investigations have addressed the performance of materials and techniques for clinical management of NCCLs ${ }^{12-14,28}$. Yet, it is important to highlight that each type of lesion has a different etiological factor and, consequently, treatments and material choices should not be based on NCCLs in general, but on each specific lesion.

Therefore, glass-ionomers can be the preferable material for abfraction lesions ${ }^{9-10}$, whilst for abrasion and erosive lesions, monomeric materials seem to be preferable, given their resistance upon toothbrushing forces $^{8-9}$ and acidic erosive episodes ${ }^{29}$. Thus, professionals should also pay attention to the materials properties to resist mechanical and chemical challenges that occur in the oral environment.

Some of the materials used in these cases are considered "smart" materials with bioactive properties, as they can balance both elastic modulus with the potential to protect the altered dental tissues. Some materials used in this study presented fillers that, in contact with biological fluids, release 6 different ions, among them, fluoride and aluminum, which are helpful at preventing demineralizing challenges and contributes to the control of sensitivity. Some other studies have also appraised their ability to hinder plaque adherence to material's surface and also resist acidic conditions, among other benefits $^{30-32}$.

The concept to treat the lesions in accordance to the etiology is mandatory for Minimal Intervention Dentistry, in which the maximum preservation of dental tissue along the time and the durability of the procedures are the main goals.

\section{CONCLUSION}

In order to select which material will present the best performance to be used as a restorative material, the clinician should take into account the causal factors of the lesion that is being treated, as well as the consequences this lesion brings to the quality of the substrate. This approach helps the professionals to achieve better durability and may help to control the progression of the disease. It is also important to share information with patients in order for them to be involved in their own recovery process, which certainly helps to treat not only the lesions, but the disease itself, resulting in real benefits to the patients. Therefore, robust science conciliated with effective technological materials and participation of patients on the treatment may lead to a successful approach overtime.

\section{ACKNOWLEDGEMENTS}

This work was supported by the Coordenação de Aperfeiçoamento de Pessoal de Nível Superior - Brasil (CAPES) - Finance Code 001.

\section{REFERENCES}

1. Fejerskov O, Larsen MJ. Demineralization and remineralisation: the key to understanding clinical manifestations of dental caries. In: Fejerskov O, Nyvad B, Kidd E. Dental caries: the disease and its clinical management. 3rd ed. Oxford: Wiley Blackwell, 2015:160-69.

2. Innes NP, Frencken JE, Bjørndal L, Maltz M, Manton DJ, Ricketts D, et al. Managing carious lesions: consensus recommendations on terminology. Adv Dent Res. 2016;28:49-57.

3. Ismail AI, Pitts NB, Tellez M, Benerjee A, Deery $C$, Douglas $G$, et al. The International Caries Classification and Management System $\left(\right.$ ICCMS $\left.^{\mathrm{TM}}\right)$ an example of a caries management pathway. BMC Oral Health. 2015;15:S9.

4. Schwendicke F, Frencken JE, Bjørndal L, Maltz $M$, Manton DJ, Ricketts $D$, et al. Managing carious lesions: consensus recommendations on carious tissue removal. Adv Dent Res. 2016;28:58-67.

5. Black GV. Operative Dentistry. Chicago: Medico Dental, 1908.

6. Rees JS. The effect of variation in occlusal loading on the development of abfraction lesions: a finite element study. J Oral Rehabil. 2002; 29:188-93.

7. Borcic J, Anic I, Urek MM, Ferreri S. The prevalence of non-carious cervical lesions in permanent dentition. $\mathrm{J}$ Oral Rehabil. 2004;31:117-23.

8. Grippo JO, Simring M, Coleman TA. Abfraction, abrasion, biocorrosion, and the enigma of noncarious cervical lesions: a 20-year perspective. J Esthet Restor Dent. 2012;24: 10-23.

9. Peumans M, Politano G, Van Meerbeek B. Treatment of noncarious cervical lesions: when, why, and how. Int J Esthet Dent. 2020;15: 16-42.

10. Soares PV, Souza LV, Veríssimo C, Zeola LF, Pereira AG, Santos-Filho PC, et al. Effect of root morphology on biomechanical behaviour of premolars associated with abfraction lesions and different loading types. J Oral Rehabil. 2014;41:108-14. 
11. Tay FR, Pashley DH. Resin bonding to cervical sclerotic dentin: a review. J Dent. 2004;32: 173-96.

12. Giacomini MC, Casas-Apayco LC, Machado CM, Freitas MC, Atta MT, Wang L. Influence of erosive and abrasive cycling on bonding of different adhesive systems to enamel: an in situ study. Braz Dent J. 2016;27:548-55.

13. Oliveira B, Ulbaldini A, Sato $F$, Baesso $M L$, Bento AC, Andrade L, et al. Chemical interaction analysis of an adhesive containing 10-methacryloyloxydecyl dihydrogen phosphate (10-MDP) with the dentin in noncarious cervical lesions. Oper Dent. 2017;42:357-66.

14. Oliveira B, Ubaldini A, Baesso ML, Andrade L, Lima SM, Giannini $M$, et al. Chemical interaction and interface analysis of self-etch adhesives containing 10-MDP and methacrylamide with the dentin in noncarious cervical lesions. Oper Dent. 2018;43:E253-65.

15. De Rooij JF, Nancollas GH. The formation and remineralization of artificial white spot lesions: A constant composition approach. J Dent Res. 1984;63:864-67.

16. Kidd EA, Fejerskov O. What constitutes dental caries? Histopathology of carious enamel and dentin related to the action of cariogenic biofilms. J Dent Res. 2004;83:35-8.

17. Bazos P, Magne P. Bio-emulation: biomimetically emulating nature utilizing a histoanatomic approach; structural analysis. Eur J Esthet Dent. 2011;6:8-19.

18. Bazos P, Magne P. Bio-Emulation: biomimetically emulating nature utilizing a histoanatomic approach; visual synthesis. Int $\mathrm{J}$ Esthet Dent. 2014;9:330-52.

19. Boing TF, de Geus JL, Wambier LM, Loguercio $\mathrm{AD}$, Reis $\mathrm{A}$, Gomes OMM. Are glass-ionomer cement restorations in cervical lesions more long-lasting than resin-based composite resins? A systematic review and meta-analysis. J Adhes Dent. 2018;20:435-52.

20. Ebaya MM, Ali Al, Mahmoud SH. Evaluation of marginal adaptation and microleakage of three glass ionomer-based class $V$ restorations: in vitro study. Eur J Dent. 2019;13:599-606.

21. Van Meerbeek B, Yoshihara K, Yoshida Y, Mine A, De Munck J, Van Landuyt KL. State of the art of self-etch adhesives. Dent Mater. 2011;27:17-28.

22. Yoshihara K, Yoshida $\mathrm{Y}$, Hayakawa $\mathrm{S}$, Nagaoka N, Kamenoue S, Okihara $T$, et al. Novel fluoro-carbon functional monomer for dental bonding. J Dent Res. 2014;93:189-94.

23. Soares PV, Santos-Filho PC, Soares CJ, Faria VLG, Naves MF, Michael JA, et al. Non-carious cervical lesions: influence of morphology and load type on biomechanical behaviour of maxillary incisors. Aust Dent J. 2013;58:306-14.
24.Jakupović S, Anić I, Ajanović M, Korać S, Konjhodžić A, Džanković $A$, et al. Biomechanics of cervical tooth region and noncarious cervical lesions of different morphology; threedimensional finite element analysis. Eur J Dent. 2016;10:413-18.

25. Hussainy SN, Nasim I, Thomas T, Ranjan M. Clinical performance of resin-modified glass ionomer cement, flowable composite, and polyacid-modified resin composite in noncarious cervical lesions: One-year follow-up. J Conserv Dent. 2018;21:510-15.

26. Oz FD, Kutuk ZB, Ozturk C, Soleimani R, Gurgan S. An 18-month clinical evaluation of three different universal adhesives used with a universal flowable composite resin in the restoration of non-carious cervical lesions. Clin Oral Investig. 2019;23:1443-52.

27. Santos MJ, Ari N, Steele S, Costella J, Banting D. Retention of tooth-colored restorations in non-carious cervical lesions--a systematic review. Clin Oral Investig. 2014;18:1369-81.

28. Loguercio $A D$, Bittencourt $D D$, Baratieri $L N$, Reis A. A 36-month evaluation of self-etch and etch-and-rinse adhesives in noncarious cervical lesions. J Am Dent Assoc. 2007;138:507-14.

29. Honório HM, Rios D, Francisconi LF, Magalhães AC, Machado MAAM, Buzalaf MAR. Effect of prolonged erosive $\mathrm{pH}$ cycling on different restorative materials. J Oral Rehabil. 2008;35:947-53.

30. Rusnac ME, Gasparik C, Irimie AI, Grecu AG, Mesaroş AS, Dudea D. Giomers in dentistry - at the boundary between dental composites and glass-ionomers. Med Pharm Rep. 2019;92: 123-28.

31. Shimazu K, Ogata K, Karibe H. Cariespreventive effect of fissure sealant containing surface reaction-type pre-reacted glass ionomer filler and bonded by self-etching primer. J Clin Pediatr Dent. 2012;36:343-47.

32. Yoneda M, Suzuki N, Hirofuji T. Antibacterial effect of surface pre-reacted glass ionomer filler and eluate-mini review. Pharm Anal Acta. 2015;6:349. 


\section{CONFLICTS OF INTERESTS}

The authors declare no conflicts of interests.

\section{CORRESPONDING AUTHOR}

\section{Prof. Dr. Linda Wang}

Department of Operative Dentistry, Endodontics and Dental Materials

Bauru School of Dentistry-FOB-USP

Alameda Octávio Pinheiro Brisolla, 9-75,

17012-901 Bauru - SP, Brazil

Phone/Fax: +55-14-3235-8323

E-mail: wang.linda@usp.br 